Columbia Law School

Scholarship Archive

2013

\title{
(Crime) School is in Session: Mapping Illegal Earnings to Institutional Placement
}

Holly Nguyen

holly@umd.edu

Thomas Loughran

tloughran@crim.umd.edu

Ray Paternoster

rpaterno@umd.edu

Jeffrey Fagan

Columbia Law School, jfagan@law.columbia.edu

Follow this and additional works at: https://scholarship.law.columbia.edu/faculty_scholarship

Part of the Criminal Law Commons, Criminal Procedure Commons, and the Law and Society Commons

\section{Recommended Citation}

Holly Nguyen, Thomas Loughran, Ray Paternoster \& Jeffrey Fagan, (Crime) School is in Session: Mapping Illegal Earnings to Institutional Placement, ColumBIA PUBLIC LAW ReSEARCH PAPER No. 13-340 (2013).

Available at: https://scholarship.law.columbia.edu/faculty_scholarship/1795

This Working Paper is brought to you for free and open access by the Faculty Publications at Scholarship Archive. It has been accepted for inclusion in Faculty Scholarship by an authorized administrator of Scholarship Archive. For more information, please contact scholarshiparchive@law.columbia.edu. 


\title{
Columbia Law School
}

Public Law \& Legal Theory Working Paper Group

Paper Number 13-340

\section{(Crime) School is In Session: Mapping Illegal Earnings to Institutional Placement}

\author{
Holly Nguyen \\ Thomas A. Loughran \\ Ray Paternoster \\ Department of Criminology and Criminal Justice \\ University of Maryland \\ Jeffrey Fagan \\ Columbia Law School \\ Alex R. Piquero \\ University of Texas at Dallas \\ Program in Criminology
}

March 1, 2013 


\title{
(Crime) School is In Session: Mapping Illegal Earnings to Institutional Placement
}

\author{
Holly Nguyen \\ Thomas A. Loughran \\ Ray Paternoster \\ Department of Criminology and Criminal Justice \\ University of Maryland \\ Jeffrey Fagan \\ Columbia Law School \\ Alex R. Piquero \\ University of Texas at Dallas \\ Program in Criminology \\ *** Draft - 1 March 13*** \\ Do Not Cite Without Permission of the Authors
}

\begin{abstract}
All correspondence should be addressed to Tom Loughran, Department of Criminology, University of Maryland, 2220 Lefrak Hall, College Park, MD 20742, or tloughra@umd.edu. The project described was supported by funds from the following: Office of Juvenile Justice and Delinquency Prevention, National Institute of Justice, John D. and Catherine T. MacArthur Foundation, William T. Grant Foundation, Robert Wood Johnson Foundation, William Penn Foundation, Center for Disease Control, National Institute on Drug Abuse (R01DA019697), Pennsylvania Commission on Crime and Delinquency, and the Arizona Governor's Justice Commission. We are grateful for their support. The content of this paper, however, is solely the responsibility of the authors and does not necessarily represent the official views of these agencies.
\end{abstract}




\begin{abstract}
A growing consensus suggests that incarcerating offenders tends to have either null or criminogenic effects at both the individual and neighborhood levels. There is also further evidence that there are unintended consequences of incarcerating juvenile offenders such as delayed psychosocial development and school dropout. The current study considers a much less examined hypothesis - that correctional environments can facilitate the accumulation of "criminal capital" and might actually encourage offending by serving as a school of crime. Using unique panel data from a sample of serious juvenile offenders, we are able to identify the criminal capital effect by considering illegal earnings and information regarding institutional stays over a seven year period. We have two separate measures that tap into the different mechanisms by which offenders can acquire criminal capital within institutions: the prevalence of friends in the facility who have committed income generating crimes and the length of institutional stays as a cumulative dosage. We find that both facility measures have independent positive effects on an individual's daily illegal wage rate, even after controlling for important time varying covariates. Theoretical and policy implications are discussed.
\end{abstract}




\title{
(Crime) School is In Session:
}

\section{Mapping Illegal Earnings to Juvenile Institutional Placement}

\author{
"Prison is like high school with knives." \\ Raegan Butcher
}

\section{INTRODUCTION}

There are approximately 80,000 youth in the U.S. who are placed in institutions each year at the cost of billions of dollars annually (Office of Juvenile Justice and Delinquency Prevention, 2012). Yet despite considerable resources and investments in these facilities to both protect society and reform offenders, institutional placement ${ }^{1}$ of juvenile offenders often has unintended consequences. A growing consensus suggests that incarcerating offenders tends to have either null or criminogenic effects at both the individual (Nagin, Cullen and Jonson, 2009; Tonry, 1999) and neighborhood levels (Clear, Rose and Ryder, 2001; Fagan, West and Holland, 2003). For instance, Nieuwbeerta, Nagin and Blokland (2009) found that first time imprisonment was associated with an increase in subsequent criminal activity, while in a study using data from a population of Florida offenders Bales and Piquero (2012) found that imprisonment produced a criminogenic effect on re-offending compared to non-incarcerative sanctions. This criminogenic effect is heightened when incarcerating adolescents. For example, Loughran et al. (2009) not only found that there was no marginal benefit to longer institutional placements for juveniles, but also that the likelihood of re-arrest and reoffending was no different, and perhaps slightly higher for juveniles who were placed in institutions compared to those given probation.

\footnotetext{
${ }^{1}$ To be clear, juvenile offenders are placed in various types of settings, each with a different focus (e.g. correctional vs. residential). We use the term "institution" to represent all settings in which juveniles are placed.
} 
In addition to potentially criminogenic effects, there are further unintended consequences of institutionalizing juvenile offenders. Adolescents who are institutionalized are at a key developmental phase of their life and as such are especially vulnerable to negative outcomes such as delayed psychosocial development (Dmitrieva et al., 2012; Mulvey and Schubert, 2012a) and school dropout (Snyder, 2004). Void of the necessary education and skills to successfully integrate into conventional society, many youth released from custody facilities are at high risk to reoffend (Moore, 1996; Blomberg, Bales, Mann, Piquero, and Berk, 2011).

If the institutional placement of juveniles is not producing a reduction in offending through either a rehabilitation or specific deterrent effect, this is clearly an important consideration in a cost-benefit calculus of allocating resources. The current study considers the much less examined hypothesis which could tilt this cost-benefit consideration even furtherthat institutional placement might actually encourage offending by serving as a 'school of crime'. That is, correctional environments can facilitate the accumulation of "criminal capital" (e.g., Miller and Ohlin, 1985; Bayer, Hjalmarsson and Pozen, 2009; Dishion and Dodge, 2005; Dishion, McCord and Poulin, 1999), which can be defined as the stock of knowledge and skills that can facilitate the returns to crime (McCarthy and Hagan, 1995). Thus, in addition to fostering greater recidivism and hindering psychosocial development, institutionalizing adolescents could create more criminally competent offenders, which can have an important and prolonged impact on criminal career development. For example, the rational choice literature in criminology suggests that offenders are highly sensitive to rewards, which are especially salient in adolescence and in disadvantaged communities (Anderson, 1999; Fagan and Freeman, 1999). Similarly, life course and developmental scholars find that offenders who receive greater returns 
to crime are much less likely to desist from offending (Laub and Sampson, 2003; Pezzin, 1999; Piliavin et al., 1986; Shover and Thompson, 1992).

The substantial cost of incarcerating offenders and the unintended consequences of confinement have been well established in the criminological, economics, and prevention science literatures (Clear, 2007; Cohen and Piquero, 2009). In the current study, we examine if institutional placement fosters greater criminal capital and thus creates more criminallycompetent offenders. However, unlike prior studies which focus on recidivism as an outcome, we use unique panel data from a sample of serious juvenile offenders for whom we observe reported illegal earnings to study monetary returns to illegal activity after placement. Similar to legal labor market studies which use measured earnings_-rather than simply if an individual is employed or not—-to study the returns to education (Angrist and Krueger, 1991; Card, 1995, 1999; Carneiro, Heckman and Vytlacil, 2011), the use of illegal earnings provides us with a proxy to measure offender 'success' in the illegal labor market after placement. This affords an opportunity to directly address the notion that institutions are crime schools by modeling our outcome as the returns to accumulated criminal capital. In so doing, this study departs from alternative theoretical explanations designed to explain why some offenders re-offend when released from an institution but instead addresses why some offenders do better at crime.

The paper proceeds as follows: First, we review the extant literature which argues that institutional placement fosters criminal capital. Second, we present several theoretical reasons why recidivism is only one proxy to measure criminal capital, and it may not be the ideal one. Third, we discuss the issue of selection bias in correctional research and present our identification strategy. Fourth, we present results which imply a positive yet marginally 
diminishing facility effect to illegal returns. Finally, we discuss our findings in light of their policy and theoretical implications.

\section{INSTITUTIONS AS "SCHOOLS OF CRIME”}

There are several ways that being placed in an institution can increase the returns to crime. The most notable way is through the accumulation of criminal capital. Criminal capital can be conceptualized as the criminal form of the widely influential concept of human capital, defined as "activities that influence future real income through embedded resources in people" (Becker, 1962: 9). ${ }^{2}$ The accumulation of criminal capital can stem from a variety of informal sources. Sutherland (1947) is most notable for his statement regarding this process. He notes that "learning of criminal behavior occurs within intimate personal groups...the learning includes (a) techniques of committing the crime, which are sometimes very complicated, sometimes very simple; (b) the specific direction of motives, drives, rationalizations, and attitudes" (p.9). The importance of criminal embeddedness and criminal capital has also been recognized in other criminological literature. $^{3}$ A number of ethnographic works illustrate the process of gaining skills and information in successful criminal endeavors (e.g., Shaw, 1931; Sullivan, 1989; Sutherland, 1937; Steffensmeier and Ulmer, 2005; Padilla, 1992). Cloward and Ohlin (1960:147) for example note that "motivations and pressures toward deviance do not fully account for deviant behavior any more than motivation and pressures toward conformity account for conforming behavior. The individual must have access to a learning environment and, once having been

\footnotetext{
${ }^{2}$ Quantifying the monetary returns associated with the accumulation of human capital (e.g., the returns to education) is a widely studied problem in empirical economics (e.g., Carneiro, Heckman, and Vytlacil, 2011).

${ }^{3}$ The idea that formal control institutions can be "schools for crime" has a long history both in criminology and literature. In Victorian England, Dickens wrote extensively about the malignant consequences of bridewells, workhouses, and debtors prisons (Richardson, 2012). At about the same time, the journalist and neophyte social researcher Henry Mayhew conducted comprehensive examinations of both the London poor (most of whom had been touched by workhouses or prisons), and London prisons. His books London Labor and the London Poor (2012) and The Criminal Prisons of London (2011) document the fact that Victorian institutions for the poor and criminal were more successful in teaching crime and vice than they were at reforming. A similar theme was picked up by the life histories of Chicago School theorists, as detailed in Shaw's The Jack Roller (1966).
} 
trained, must be allowed to perform his role". Scholars have examined the role of personal intimate groups in fostering criminal capital in the contexts of families (Hagan, 1996), gangs (Levitt and Venkatesh, 2000); deviant peers (Dishion et al., 1999; McCarthy and Hagan, 1995) and within correctional facilities (Bayer et al., 2007; Ouss, 2011).

To our knowledge, only a few studies have directly addressed the idea that being incarcerated generates criminal capital. Most rigorously, Bayer, Hjalmarsson, and Pozen (2009) explicitly hypothesize that an individual can build criminal capital while incarcerated. Using a sample of juvenile offenders from Florida, Bayer et al. found strong institutional peer effects in that increased exposure to peers with a history of a specific crime type increases the likelihood that the subject (who has already committed that crime type) will commit that particular crime type upon release. Bayer et al. (2009) showed that institutional contexts can foster criminal embeddedness in social relations with like-minded and like-skilled offenders and enhance learning of crime skills, thereby resulting in more prolific offending. Bayer and colleagues (2009) speculate that one of the mechanisms underlying observed peer effects is that "peers may increase knowledge about specific crimes, thereby increasing returns to committing those crimes" (p. 136). The authors however, were not able to test this conjecture and only measured recidivism as the outcome. Ouss (2011) tested how interactions among prison cell-mates influenced recidivism post release among federal prisoners in France. Ouss hypothesized that if prisons are truly "schools of crime" and there is a transfer of knowledge, crimes that require more skill (i.e., drug dealing and theft) would be more influenced by peers compared to less skill-intensive crimes (i.e., drinking and driving). Results showed that indeed, theft and drug dealing have the largest peer effect, whereas there were no peer effects for driving under the influence and assault. Thus, individuals who had prior experience with theft or drug dealing and 
spent time with cellmates who also committed theft and/or drug dealing were more likely to commit those crimes upon release. ${ }^{4}$

Recently, Hutcherson (2012) used the National Longitudinal Survey of Youth to look at the role of incarceration on illegal earnings and found that individuals who had prior incarceration made greater annual illegal earnings compared to individuals who have never been incarcerated. Hutcherson speculated that incarceration provides opportunities for individuals to gain criminal social capital and knowledge from skilled offenders, which translates to greater annual illegal earnings. In general, these findings lend support to the hypothesis that correctional institutions can serve as schools of crime. However, further empirical attention should be given to the relationship between institutions and illegal earnings for several reasons. First, the primary dependant variable, annual illegal income, may be a proxy for frequency of offending, which is not accounted for in the models. Second, Hutcherson's analyses only looked at whether an individual spent time in jail/prison or not. Finally, zero earners were included in the analysis using a tobit model, which essentially treats the zeros as a corner solution outcome. This is inconsistent with most research on wage equations, which typically tend to include only those individuals earning some wages and treat non-market participants as a problem of sample selection (see Bushway et al., 2007; Heckman 1974).

Studies in the prevention science literature also show that group interventions can have unintended effects. Dishion, McCord, and Poulin (1999) use the term "deviancy training" to define the "process of contingent positive reactions to rule-breaking discussions" (p.756). They examined group intervention programs in the Adolescent Transitions Program Study and found

\footnotetext{
${ }^{4}$ It is important to note that some scholars, such as Gottfredson and Hirschi (1990) argue that there is no skill required for the commission of most crimes. At the same time, qualitative work in criminology, especially in burglary (Wright and Decker, 1994), drug dealing (Jacobs, 1996), and violent offending (Topalli, 2005) suggests that offenders do possess specialized knowledge with regard to the successful commission of crimes, target selection, and detection avoidance.
} 
that aggregating youth with conduct problems resulted in negative outcomes such as an increase in tobacco use and antisocial behavior (see also Felman and Caplinger, 1977; Feldman et al., 1983; Leve and Chamberlain, 2005; Poulin et al., 2001). There is also an indication that interventions that cluster antisocial adolescents have long term negative outcomes. The Cambridge-Summerville Youth Evaluation Study randomly assigned matched pairs of high risk children to treatment and control groups (McCord, 1978; 1981). Adolescents assigned to the treatment groups were encouraged to participate in group activities such as sporting events and summer camps. Researchers found that by the time the participants reached 35 years old, men who were in the treatment group were more likely to die prior to age 35 , be convicted of a serious crime, be an alcoholic, or diagnosed with a psychiatric disorders outcome. In sum, this body of research corroborates the criminal capital literature and provides empirical evidence for the notion that correctional institutions and interventions can have criminogenic effects.

\section{BEYOND RECIDVISM}

The bulk of the empirical evidence suggests that incarcerating offenders has either null or criminogenic effects (Loughran et al., 2009; Spohn and Holleran, 2002; Petersilia, 2003; Gatti, Tremblay, and Vitaro, 2009). As such, some scholars have applied criminal capital theory to explain why some offenders accumulate criminal skills and knowledge during their incarceration and thus positively contribute to their reoffending after their release. At the same time however, concluding that correctional facilities can foster criminal capital may be premature for number of theoretical reasons.

First, using recidivism as a proxy for criminal capital confounds the criminal capital effect with several other theoretical explanations which also predict that incarceration would 
increase the likelihood of reoffending upon release. For example, it has been suggested that institutionalization severs important social bonds to the labor market, family, and other conventional institutions (Western, 2006; Pager, 2007; Manza and Uggen, 2006). Sampson and Laub (1993) note that prison prevents offenders from "knifing off" or dissolving ties to criminal opportunities. Labeling theorists posit that incarceration serves to isolate, and stigmatize individuals engaged in criminal behavior (Lofland, 1969). Individuals subject to isolation and rejection are hypothesized to then internalize the offender label and continue in a life of crime (Becker, 1963; Lemert, 1973). Moreover, offenders encounter obstacles that prevent them from participating in conventional society in a process called state dependence, which states that constraints, preferences, or costs that govern future outcomes are altered by past events (Nagin and Paternoster, 1991). Finally, strain theorists argue that imprisonment creates negative emotional states such as anger and negative emotionality. Upon release, offenders are deprived of adaptive coping mechanisms and often resort to crime to alleviate the pains of reintegration (Agnew, 2002; Listwan et al., 2013). In sum, while each of these explanations highlight different mechanisms, they all make the same prediction that incarceration leads to recidivism, making it difficult to disentangle a criminal capital effect from other mechanisms of persistence.

Second, studies that have looked at the accumulation of criminal capital in institutions have measured recidivism by contact with the criminal justice system. For example, Bayer et al. (2009) measured recidivism as subsequent reconviction within one year of release and Ouss (2011) measured recidivism as the reappearance in the public defender's caseload. Accumulation of criminal capital however, can also include knowledge and skills that help in avoiding detection. In his 1941 commentary on crime prevention, O.W. Wilson noted: "for [some] prison proved to be a finishing school of crime from which they graduated and consequently are so 
adept in their improved techniques to successfully avoid future apprehension" (p.33). More recently, Kazemian and LeBlanc (2007) looked at a sample of adjudicated males from Montreal Quebec and found that there was variation in individuals' ability to avoid detection. Morselli et al. (2006) observed that offenders who had criminal mentors spent on average nine days less in prison. Bouchard and Nguyen (2009) found that adolescents embedded in large adult networks were more likely to avoid arrest. They hypothesized that adolescents who are embedded in criminal networks containing a large number of adults may be privy to tutelage relationships. Thus, it may be that contact with the criminal justice system subsequent to institutionalization is a proxy for being an inept criminal.

Fortunately, theoretical work concerned with criminal capital provides predictions beyond reoffending. McCarthy and Hagan (1995: 89-90) noted the limitations of relying on the frequency of criminal activity as an outcome of criminal capital. They wrote:

Our measures of frequency of criminal activity are to some extent proxies of criminal success. That is, although continuation of criminal activity does not always denote prosperity in it ... success can be measured more directly. Measurement of financial returns and profits obtained are an important possibility. Other indicators may include the ability to avoid detection or apprehension, career duration, specialization, and prestige within criminal hierarchies.

Unlike other theoretical explanations that predict offending, a theory of criminal capital would predict greater success in offending. Therefore, given the difficulty of disentangling the crime school effect from other mechanisms that would predict reoffending, criminal earnings can serve as another equally important indicator of criminal capital accumulation.

Finally, it is likely that the positive effects of institutional placement on the returns to crime can stem from sources in addition to criminal capital. Signaling theory, which has been formalized in labor economics, suggests that in the face of asymmetric or incomplete 
information, employers rely on indicators or "signals" regarding an individual's potential productivity (Arrow, 1973; Spence, 1973). Signaling theory makes similar predictions that human capital theory would-i.e., that wages should increase with education (Arrow, 1973). ${ }^{5}$ While human capital theory focuses on the role of education in producing skills and higher productivity, signaling theory focuses on education as a screening device or filter used by employers to sort individuals of differing abilities and identify individuals who are the most valuable. Unlike human capital theory however, the signaling perspective has seldom been used in criminological discourse. ${ }^{6}$ One exception is Gambetta (2009) who used signaling theory to explain how mafia members establish trust and navigate their way through the underworld. According to Gambetta, prison sends a signal to the illegal labor market that the individual is experienced and has made a costly investment in the criminal lifestyle, which makes him/her a more attractive and trustworthy co-offender: "just being a prisoner is a clear and simple sign that one is criminally inclined" (p.11).

In addition to the fostering of criminal skills or conveying a signal to the illegal labor market about one's criminal inclination, institutionalization can offer individuals opportunities to form weak ties, which can give offenders an advantage in the illegal market. Weak ties are relationships that are characterized by infrequent contact, an absence of emotional closeness, and no history of reciprocal favors. Granovetter (1973) forwarded the idea of the "strength of weak ties", which suggests that ties that require little time investment and energy can be a more fecund

\footnotetext{
${ }^{5}$ Though they both acknowledge the value of education in the labor market, it is important to note that human capital theory and the signaling perspective offer very different theoretical explanations on the causal mechanisms at work, and in fact yield different predictions. For instance, out of signaling models falls the idea that education has negative externalities, which we believe is vitally prescient in the crime school analog. We return to this idea in the discussion.

${ }^{6}$ There have been recent applications of signaling theory in prisoner reentry. A special issue of Criminology and Public Policy (2012) was dedicated to applying signaling theory to predicting future offending among released prisoners. Bushway and Apel (2012) provided an alternative view of the utility of work programs in the prisoner reentry process.
} 
source of information and opportunity than stronger social ties. In terms of looking for a job or gaining important information, it is the weak ties in a person's local network that provides an important source of information and opportunity. Similarly, Burt (1992) highlighted the importance of brokerage positions across structural holes. Brokers are individuals who connect groups of individuals who otherwise would not be connected. As such, individuals in brokerage positions are a valuable source of social capital and have been associated with higher wages and promotions (Burt, 2002; see also Lin, 2001). Several studies have also found that weak ties play a beneficial role in an offender's instrumental returns. Tillman and Indergaard (1999) found that white-collar criminals who were in brokerage positions used their positions to defraud the health insurance industry. Guided by Burt's structural holes theory, Morselli and Tremblay (2004) surveyed a Quebec inmate population about their network of contacts and monthly income from criminal activities prior to incarceration. They found that offenders with greater amounts of nonredundant contacts in their network had more opportunities which led to greater criminal earnings. These findings suggest that certain relationships that are not necessarily part of an individual's intimate social group and certain structural positions in a person's network can have an important and positive effect on an offender's illegal wages.

In sum, scholars have long noted that institutional placement can foster criminal capital. Yet, empirical inquiry into the "criminal capital effect" has been scant. The few studies that do place criminal capital as a key subject of empirical inquiry find support for the notion that offenders do accumulate criminal capital when institutionalized. However, extant studies use recidivism as the key outcome, which can be somewhat problematic. In addition to fostering criminal capital, there may be other reasons why incarceration can contribute to greater illegal wages. The signaling perspective and social capital theory also offer insight into this process. To 
be sure, these explanations are not mutually exclusive and in fact can be complementary in explaining variations in legal and illegal wages. However, they do emphasize different aspects of the relationship between incarceration and illegal wages.

\section{IDENTIFICATION IN THE FACE OF SELECTION BIAS}

The dominant methodological hurdle to identifying the effect of institutional placement on subsequent outcomes-regardless of which outcome-is the problem of selection bias. Ideally, the treatment effect of placement would be determined by comparing the effect of institutionalization for a given juvenile with the outcome for that same individual had they not been institutionalized. Unfortunately, we can only observe one of these counterfactual outcomes - the fundamental problem of causal inference. Instead, what researchers must do is to compare those institutionalized with different individuals not institutionalized with full knowledge that individuals who are selected, i.e., individuals who select into placement, or longer spells of placement, likely are very different in important and preexisting ways from those who do not. Therefore, the issue of finding the appropriate counterfactual becomes of primary importance.

The inherent problem of selection in the corrections/recidivism literature has been dealt with in several ways. Perhaps the most common strategy in criminology is to estimate a regression-based model with a cluster of explanatory or control variables and make a selectionon-observables assumption, or in other words assume that all of observed covariates are capable of explaining differences in treatment assignment. This assumption is commonly manifested in the use of propensity score methods to compare placement (i.e., treated) cases to probation (i.e., control) cases. For instance, Loughran et al. (2009) were able to rule out 66 covariates, over a broad range of categories, as confounders before identifying an essentially null effect of 
placement on recidivism among a sample of serious juvenile offenders. Similarly, in a study of Dutch adults Snodgrass et al. (2011) found a similarly flat dose-response relationship after eliminating criminal history and crime type as potential confounders. Some scholars have employed propensity score matching within trajectory groups, which attempts to create even greater balance between treatment and control groups (e.g., Haviland and Nagin, 2005;

Nieuwbeerta, Nagin and Blokland, 2009). However, the selection-on-observable assumption can quickly become less tenable — and often heroic_-if the number of observed covariates is small and/or does not include important potential confounders. It is also important to note that in the case where there are unobserved confounders, propensity score methods are ineffective at solving the selection problem. Manski and Nagin (1998), under much weaker assumptions, derive bounds, instead of point estimates, for the effect of institutional placement on recidivism among a sample of juvenile offenders from Utah. However, under such weak assumptions, these bounds yield an ambiguous conclusion as only under stronger assumptions about the nature of judges' sentencing strategy were Manski and Nagin able to identify the algebraic sign of the point estimate.

A second strategy used to deal with the inherent selection problem is the instrumental variable approach. Berube and Green (2007) and Green and Winik (2010) all used similar instruments to achieve exogenous variation: they take advantage of the fact that, in some jurisdictions, defendants are assigned randomly to judges who vary in sentencing tendencies. This sets the stage for a test of whether exogenous variation in sentencing affects rates of recidivism. Results generally suggest that there is little relationship between sentence length and recidivism. Turner (2009) and Abrams (2011) use data from Clark County, Nevada and random assignment to attorney and heterogeneity in attorney skill as an instrument for sentence length. 
Turner's findings corroborate those of others who use the instrumental variables approach: there is little relationship between sentence length and recidivism. Abrams (2011) found heterogeneous effects of sentence length on recidivism. He found that individuals sentenced to short-periods ( 0 to 2 months) were more likely to recidivate and suggested that institutionalization could, in fact, benefit novice criminals because criminals learn about new techniques and information useful in avoiding apprehension. ${ }^{7}$ The instrumental variables approach is a creative strategy that produces consistent estimates in the presence of omitted variables. However, the utility of this approach rests heavily on the instrument itself. If the instrument is invalid or weak this would result in large standard errors, and not be much of an improvement over the standard ordinary least squares estimator. As such, in some cases the instrumental variables approach can cause more problems than they solve (see Bound, Jaeger, and Baker, 1995).

The availability of panel data provides yet another way to deal with selection. It is possible and quite likely that selection bias plaguing identification of a placement effect results from fixed unobserved heterogeneity. For instance, in legal labor market studies, economists often refer to unobserved 'ability' or 'motivation' as being an important determinant in an earnings equation. Any positive correlation between entry into the market and productivity indicators can be attributed to selection rather than causality, which is a form of omitted variable bias (Wooldridge, 2009). In the present case, there are several unobservable variables that likely strongly influence illegal earnings. Factors such as criminal propensity, ability, intelligence and motivation are difficult to quantify and may not necessarily have reasonable proxies.

\footnotetext{
${ }^{7}$ Other methods based on exogenous variation have been used to confront the selection problem, such as experiments (Berecochea and Jaman, 1981; Gaes and Camp, 2009), regression discontinuity approaches (Chen and Shapiro, 2007; Hjalmarsson, 2009), and natural experiments (Drago, Galiati, and Vertova, 2009).
} 
Criminologists have speculated about the role of criminal ability (Morselli and Tremblay, 2004; Steffensmeier and Ulmer, 2005; Wright and Decker, 1994), which if correlated with both the wage offer and factors leading to higher likelihood of placement can, if ignored, result in important misspecification of the model.

To address issues of unobserved heterogeneity, we rely on a unique sample of serious adolescent felony offenders who have provided detailed information about their experiences in incarceration and their illegal income over a seven year period. Panel data offer a way to ameliorate the problem of omitted variable bias by eliminating fixed unobservable heterogeneity via estimation using individual fixed effects. The main strength of using this estimator to identify the impact of the 'crime school' effect on illegal wages is that our two central variables, length of incarceration and peer exposure in facilities, are as good as randomly assigned conditional that the unobserved heterogeneity is fixed (Angrist and Pischke, 2009). If this assumption is met, then the fixed effects estimator yields consistent parameter estimates. To the best of our knowledge, this research question, methodological approach, and longitudinal nature of the data we employ have not been considered in previous research.

\section{CURRENT STUDY}

Given the implications for using recidivism as a proxy for criminal capital, we address the notion that prisons are schools of crime by identifying the criminal capital effect through an important measure of criminal achievement—illegal wages. To this end, we provide important contributions to the extant research in a number ways. First, we are able to identify the criminal capital effect by using detailed information on within individual change in the illegal wage rate and information regarding institutional stays over a seven year period. Second, we have a measure of the prevalence of friends in the facility who engage in four income-generating 
behaviors. Criminal capital theory underscores the importance of the transmission of specialized skills and knowledge (Cloward and Ohlin, 1960; McCarthy and Hagan, 2001; Sutherland, 1947). We, therefore, expect that exposure to peers who engage in income generating crimes will foster greater criminal capital. Our measure of peer exposure is specific to institutional peers and allows each individual his/her own peer exposure.

In addition to peer exposure, we measure the length of institutional stays as a cumulative dosage. This provides us with two separate measures that tap into the different mechanisms by which offenders can acquire criminal capital within institutions. Guided by the literature on the effects of institutionalization and criminal capital, we hypothesize that spending more time institutionalized and having greater exposure to deviant peers within the facilities will generate greater criminal capital, measured by a significant positive effect on one's illegal wage rate. Our study is among the few to consider the notion that institutions are schools of crime and the only one to do so in a longitudinal manner. To this end, we believe that our findings will be highly relevant for both theory and policy.

\section{DATA}

The current study uses a subset of $N=352$ individuals enrolled in the Pathways to Desistance study, a longitudinal investigation of the transition from adolescence to young adulthood in a sample of serious adolescent offenders. Study participants are adolescents who were found guilty of a serious offense (almost entirely felony offenses) in the juvenile or adult court systems in Maricopa County, AZ or Philadelphia County, PA during the recruitment period (November, 2000 through January, 2003). Participants were ages 14 to 17 at the time of their enrollment into the study $(\mathrm{M}=16.5)$, and data were collected at ten consecutive follow-up interviews. The first six interviews correspond to six-month observational periods over 36 
months and the remaining interviews are twelve-month observational periods. Information regarding the rationale and overall design of the study can be found in Mulvey et al. (2004), while details regarding recruitment, a description of the full sample, and the study methodology are discussed in Schubert et al. (2004). ${ }^{8}$

The present analysis consider $N=352$ individuals who report illegal earnings in at least two observational periods to allow us to construct a longitudinal illegal earnings profile. ${ }^{9}$ The study sample, like the overall sample, is comprised mainly of non-white (45\% African American, $27 \%$ Hispanic) males (93\%). In each period, we observe for each individual their total reported illegal earnings, the number of days spent in one of five types of institutions ${ }^{10}$, the number of peers in the institutions that committed income-generating crimes, along with their age, incomegenerating crimes variety proportion (described below), their criminal experience, and their criminal embeddedness. Information regarding the total amount of money earned from illegal activity each month was recorded by using a life-event calendar. This information was aggregated to provide earnings information for each of the follow-up periods. Methods for constructing life-event calendars have been shown to be reliable in studies of criminal offending, antisocial behavior, and mental health service use (Caspi et al., 1996; Horney, Osgood, and Marshall, 1995; Morris and Slocum, 2010; Roberts and Horney, 2010).

\section{Outcome variable}

\footnotetext{
${ }^{8}$ Additional information about the study can be found at: www.pathwaysstudy.pitt.edu.

${ }^{9}$ A total of $N=1,354$ adolescents are included in the study, representing approximately one in three adolescents adjudicated on the enumerated charges in each locale during the recruitment period. Yet, not every individual reported involvement in illegal income-generating activity in all periods. Out of 1,354 participants, 615 unique individuals report illegal earnings at some point over the entire study period. Among these individuals, 263 subjects reported illegal wages for only one recall period. Therefore, 352 subjects have at least two recall periods in which they report illegal earnings, and hence are able to be included in this analysis. We consider the important implications of this sample selection issue in more detail below in both the methods and discussion sections.

${ }^{10}$ The types of facilities include: jail/prison, detention, youth detention, contract residential, and contract residential mental health.
} 
Daily illegal wages: We use the daily illegal wage rate (instead of aggregate earnings over an observation period) to account for the different amounts of time individuals are on the street, and thus capable of generating illegal earnings, during any given observation period. Daily illegal wage rate was calculated by dividing the total self-reported illegal earnings for a recall period by the number of days the subject spent in the community. The number of days the subject spent in the community was calculated by multiplying the total number of days in the recall period by the proportion of time the subject did not spend in an institution. The mean daily illegal wage rate is $\$ 205.04$; however due to the skewness, which is common with self-reported earnings data, we applied a natural logarithmic transformation to create our dependent variable. Figure 1 shows that the log daily illegal wage rate has a mean of 3.75 and a standard deviation of $1.83 .^{11}$

$\sim$ Figure 1 about here

\section{Independent variable}

We operationalize facility exposure in two unique ways: cumulative number of days in custody and maximum peer exposure within the facility.

Number of days in custody: To determine the relationship between the length of stay in custody and the illegal wage rate, we summed the total number of days that an individual spent in custody across the five facilities. The average total number of days an individual was in custody is 65.08 (including zeros) over a six month observation period. The total number of days was summed to create a cumulative score of the number of days institutionalized over the course of the seven-year follow-up.

\footnotetext{
${ }^{11}$ Past results find similar illegal wage rates. For example, Levitt and Venkatesh (2000) found that the average monthly wage for low level dealers is $\$ 140-200$, whereas individuals in higher positions earned considerably more. McCarthy and Hagan (2001) found that the average daily wages for homeless youth engaged in drug dealing was $\$ 101$. Freeman (1996) found that among a sample of Boston youth, occasional offenders earned \$250 and weekly offenders earned $\$ 448$.
} 
Facility peer exposure: Individuals were asked "While you were at facility x, of the friends you had there, how many have ever done the following things? We are interested in lifetime behavior, not just behavior within the institution or program". Subjects chose an answer on a Likert scale ( $1=$ none; $2=$ few; $3=$ some; $4=$ most; $5=$ all). There were a total of 12 items ranging from destroying property to entering a building to steal. ${ }^{12}$ We constructed an economic scale using the four income-generating crimes (sold drugs, stealing something worth more than $\$ 100$, stole a car, and enter a building to steal). Because individuals often spent time at more than one facility during one observation period, and subjects chose answers from a Likert scale for each peer delinquency measure, this created a measurement challenge. We originally constructed a weighted average score of peer delinquency by institutional stay to create one Likert scale for each observation period. This scale was then summed to create a cumulative index of facility peer exposure over the seven year follow-up period, similar to our total number of days incarcerated measure. However, the two cumulative measures were highly correlated and could not be entered in the same model. Therefore, we retained the maximum rating of institutional peer delinquency that an individual reported prior to his/her reported illegal wages. Thus, facility peer exposure is operationalized as: $0=$ no facility stays; $1=$ none; $2=$ few; $3=$ some; $4=$ most $5=$ all across the four income-generating crimes. ${ }^{13}$

\section{Control variables}

Criminal experience: Past research has shown that criminal experience is positively related to total illegal earnings (Uggen and Thompson, 2003). Criminal experience is the sum of

\footnotetext{
${ }^{12}$ The 12 items include: destroy property, hit someone, sold drugs, consumed alcohol, carry a knife, carry a gun, owned a gun, fight, hurt someone in a fight, stole something worth more than $\$ 100$, stole a car, enter a building to steal.

${ }^{13}$ There were 117 out of 1117 missing values for peer ratings among individuals who reported being in a facility. Among the 117 we imputed the mean rating that the individual reported across all their stays. To ensure that imputation did not change the results, we also ran the model without the imputed values (1000 observations). Results were almost identical.
} 
the frequencies reported across 11 income offenses. ${ }^{14}$ We use these frequencies to calculate criminal experience by creating a cumulative count. According to human capital theory, experience should be positively related to earnings at a marginally decreasing rate (Mincer, 1978). As such, we include a squared term.

Adult facility: Adult facilities differ from juvenile facilities in important ways. Juvenile facilities have to goal of interrupting the juvenile's offending cycle and are rehabilitation focused and therefore provide more programs and services compared to the retributive adult system (Bishop and Frazier, 2000; Zimring, 2005). Therefore, experiences in juvenile facilities and adult facilities can be very different. (Mulvey and Schubert, 2012b). We therefore include a binary measure to indicate whether the subject spent time in an adult facility during the recall period. There were 561 unique stays across 252 individuals who spent time at an adult facility.

Age: Because age is related to both criminal experience and earnings potential, we control for age of the participant. Table 1 shows that the average age across the ten observational periods is 19.71 years. $^{15}$

Criminal embeddedness: As embeddedness in deviant networks has been shown to be an important predictor of greater criminal earnings (Morselli et al., 2006; Uggen and Thompson, 2003), we constructed measures of criminal embeddedness using the peer delinquent behavior items, which are a subset of those used by the Rochester Youth Study (Thornberry et al., 1994) to assess the degree of antisocial activity among the adolescent's peers. At each recall period, subjects were asked how many of their friends have done the particular behavior. Subjects chose an answer on a Likert scale (1=none; $2=$ few; $3=$ some; $4=$ most; $5=$ =all). There were a total of 10

\footnotetext{
${ }^{14}$ The 11 items include: shoplifted, bought/received/sold stolen property, used checks/credit cards illegally, stolen car/motorcycle, sold marijuana, sold other drugs, stole something worth more than $\$ 100$, enter a building to steal, took something by force using weapon, took something by force no weapon, and prostitution.

${ }^{15}$ Due to the irregularity of periods in which individuals report illegal earnings, since incarceration leaves large gaps in the panel, we are able to observe meaningful variation in the change in age.
} 
items ranging from destroying property to entering a building to steal. Similar to the facility peer exposure, we limited our measure of criminal embeddedness to income-generating crimes. ${ }^{16}$ Income offending proportion: Previous studies on illegal earnings have found that offending specialization increases illegal earnings (McCarthy and Hagan, 2001). We therefore included a proportion in which the numerator is the number of income offenses which were committed in the recall period and the denominator is the items which are considered incomegenerating. These are a total of 10 potential self-reported crimes that are considered incomegenerating: shoplifted, bought/received/sold stolen property, used checks/credit cards illegally, stolen car/motorcycle, sold marijuana, sold other drugs, stole something worth more than $\$ 100$, enter a building to steal, took something by force using weapon, and took something by force no weapon. The average proportion of income offending is 0.13 , across the full 10 interview periods, which indicates that most participants do not engage in a wide variety of incomegenerating crimes.

$\sim$ Table 1 about here

\section{EMPIRICAL MODEL}

We can specify the illegal wage function as follows:

logwages $_{i t}=\beta \mathrm{F}_{\mathrm{it}}+\gamma \mathrm{P}_{\mathrm{it}}+\delta \mathrm{X}_{\mathrm{it}}+\mathrm{a}_{\mathrm{i}}+\varepsilon_{\mathrm{it}}$

Where $\log$ wage $_{i t}$ represents the natural $\log$ of the rate of daily illegal wages for individual $i$ at time $t$. Let $F_{i t}$ be a vector which includes the cumulative number of days an individual has spent in a secure facility at time $t$ and its square, and let $\mathrm{P}_{\mathrm{i}}$ be an indicator regarding the level of

\footnotetext{
${ }^{16}$ Haynie and Osgood (2005) have noted one limitation of self-reported peer measures is that they may overestimate the true influence of peers. While we recognize this possibility, we offer two points as to why this potential problem would be less problematic for our findings. First, our estimator is based on identification solely from within person variability. Thus, identification is derived from any changes in level of reported peer influence, as opposed to absolute levels, and any fixed reporting bias on the part of the individual would be differenced away. Second, and more importantly, even if the peer effect is upwardly biased, this would not explain the independent days effect we observe, and in fact would only make the gap between these two effect sizes larger, therefore calling even more emphasis to a secondary mechanism beyond a 'crime school' peers explanation.
} 
exposure to the peers in the facility at time $t$. Let $X_{i t}$ be a vector of individual time varying variables such as, criminal experience, whether or not the subject spent time at an adult facility, age, the level of criminal embeddedness, and the income offending proportion, which we hypothesize are contemporaneous measures that also potentially affect criminal returns (Uggen and Thompson, 2003). Finally, let $\mathbf{a}_{\mathrm{i}}$ represent fixed unobservable individual-specific characteristics which may be affecting wages and correlated with other regressors (e.g., motivation or criminal propensity). The key parameters of interest are the vectors $\beta$ and $\gamma$, which would correspond to the effects of placement length and peers.

To estimate the parameters of this model, we employ typical estimators designed to eliminate bias due to fixed unobserved heterogeneity. Yet, as we note above in description of the sample, it is likely there are also issues with sample selectivity to consider as well. Namely, similar to studies of legal wages, individuals who do not report participation in illegal incomegenerating activities in period cannot simply be coded as having zero earnings and included in estimation, as their potential wage offer is unobserved (i.e., such observations suffer from incidental truncation). ${ }^{17}$ Simultaneously correcting for unobserved heterogeneity and sample selection bias through individual fixed effects presents a very intimidating methodological obstacle. Several econometricians have proposed assumption-heavy estimators to tackle this issue (Wooldridge 1995; Vella and Verbeek 1999), yet, perhaps in part due to their complexity, there are very few empirical applications of these methods even in the labor economics literature (see Dustmann and Rochina-Barrachina 2007). As such, a formal treatment would require a more detailed discussion of the methodological approach and requisite assumptions. Therefore, in the

\footnotetext{
${ }^{17}$ In other words, it is likely that certain individuals could earn money in the illegal market, but for whatever reason choose not to participate (e.g., they may view the risk or costs to outweigh the potential rewards). This is analogous to a well-developed problem in labor economics which originated in early studies of female labor supply (Gronau, 1974),
} 
present study, we forgo dealing directly with the sample selection issue in favor of concentrating on the problem of unobserved heterogeneity. Instead, we note that our results are likely upwardly biased estimates of the relationship to the larger population of serious offenders. However, we stress that the group to whom our findings are directly generalizable-repeat illegal wage earners-is nonetheless a highly important group to study for policy purposes.

\section{RESULTS}

Our results section consists of two main sets of analyses. First, we consider if there is an overall placement effect on illegal earnings, which is analogous to the effect of placement on recidivism considered in many other studies. Note that this overall effect does not provide insight as to any certain mechanisms. Second, we examine our indicators of facility exposure. To determine whether or not overall placement in an institution increases illegal wage rates, we first establish that there is variation in illegal wage rates between the first period in which we observe a subject's reported illegal wages and the second period in which we observe the same subject's illegal wages. Figure 2 illustrates that this is the case: some participants increase their wage rates whereas others decrease their wage rates. We also examine the distribution of the illegal wage rate conditional on our main predictors.

$\sim$ Figure 2 about here

Table 2 shows the quintiles of the cumulative number of days incarcerated and that the average of the illegal wage rate for each respective quintile increases, except for at the $80^{\text {th }}$ percentile. Similarly, facility peer exposure was also broken down into the six categories and shows a generally positive relationship with illegal wage rate.

$\sim$ Table 2 about here

OVERALL PLACEMENT EFFECT_FIRST-DIFFERENCE ANALYSIS 
To further explore whether being placed in an institution is related to a change in one's illegal wage rate, we compare the first and second observations of log illegal daily wages for individuals who were placed in a facility between the two observations and for individuals who did not spend any time in a facility. Figure 3 illustrates two important points that inform our subsequent analyses. First, on average individuals who were placed in a facility $(\mathrm{n}=259)$ increased their illegal wage rate whereas those who were not placed did not (n=93), which prompts us to move forward with investigating facility effects. More specifically, the difference between subjects who were not placed in a facility between time 1 and time 2 is $-0.031 \log$ dollars ( $p=0.909$ ) whereas the subjects who were placed in a facility between time 1 and time 2 is much larger: $.342 \log$ dollars ( $p=0.033)$. The difference-in-difference between those who were placed and those who were not placed is $0.373 \log$ dollars $(p<0.001)$, suggesting there is an important overall facility effect. Second, Figure 3 illustrates that individuals who are placed in a facility tend to have higher illegal wages to start with. A difference of means test comparing subjects who were not placed in a facility and subjects who were placed at time 1 is $-.658 \log$ dollars $(p=0.003)$. This underscores the notion that there are possible selection effects for individuals who are placed in a facility that distinguish them from their counterparts who are not placed in facilities and can also contribute to variation in illegal wage rates.

$\sim$ Figure 3 about here

To assess the relationship between all our measures, we use an identification strategy based on a first-difference estimate, which employs essentially the same logic as the fixed effects estimator but with two time points. ${ }^{18}$ Table 3 displays the results of our first difference model,

\footnotetext{
${ }^{18}$ As compared to a fixed-effects, or within-person, estimator which time-demeans each observation for every individual, the first difference estimator considers the change in each variable from time $t$ to time $t+1$. Importantly, both estimators have the important feature that differences away bias due to fixed unobserved heterogeneity, and in the case of two periods, they are mathematically equivalent.
} 
conducted in five stages. Column 1 shows diminishing marginal returns to days incarcerated, even when controlling for criminal experience, criminal embeddedness, and variety income offending (column 2). Column 3 illustrates that facility peer exposure has a positive and significant effect of illegal wage rate. The positive and significant effect of facility peers remained when we added our control variables (column 4). Finally, column 5 shows the results when we enter both facility predictors and our control variables. Both predictors exert independent effects on the illegal wage rate. To be clear, with panel data, the first-difference estimates are for the same cross section units. We initially limited our analyses to the first two time points for clarity, however 192 out of 352 subjects reported illegal wages at more than two time points. With more than two time points, the fixed effects estimator is a more efficient estimator (under the assumption that the errors are not serially correlated; [Wooldridge, 2002]); therefore, we estimate our full models using the fixed effects estimator.

$\sim$ Table 3 about here

\section{FACILITY EXPOSURE-FIXED EFFECTS}

Similar to the first difference analysis, we enter our facility measures in five separate stages. We first estimate the model using standard Ordinary Least Squares (OLS), with standard errors clustered at the individual level, to highlight the degree of bias due to selection that might be present. To be clear, any unobserved fixed differences among individuals contributing to illegal earnings would not be accounted for in these estimates. The results show that across individuals, there are increasing yet diminishing marginal returns to the number of days incarcerated across all the models. For every day spent incarcerated, there is an increase in the daily wage rate. However, the negative coefficient on the quadratic term implies this relationship increases at a decreasing rate, even when accounting for our time varying controls (column 1 and 
2). Similarly, facility peer exposure significantly increases daily wage rate and this relationship holds even after controlling for important time varying covariates (columns 3 and 4). Column 5 illustrates that both facility measures remain significant when entered in the same model: the number of days incarcerated increases the illegal wage rate at a marginally decreasing rate and the greater the facility peer exposure, the higher the illegal wage rate.

$\sim$ Table 4 about here

The fixed effects results are presented in Table 5. We proceed in the same manner as we did for the OLS models and found similar results. First, there are increasing yet diminishing marginal returns to the number of days incarcerated across all the columns. The magnitude of the effect is slightly smaller in the fixed effects models compared to the OLS model. Second, Table 5 reveals that the facility peer effect reduces by about one half but retains statistical significance even after controlling for other factors. This result suggests that the OLS estimator is upward biased, likely due to omitted variables. Similar to the number of days incarcerated, criminal experience also increases illegal wage rate at a decreasing rate. When both facility measures are simultaneously considered, both the number of days incarcerated and facility peer exposure slightly decreases in magnitude yet still remain positive and statistically significant. Community peer exposure significantly increases the illegal wage rate whereas age appears to be important across individuals but not within persons. The more types of income-generating crimes predict increases in an individual's illegal wage rate but not across individuals. Spending time in an adult facility does not have an effect on the illegal wage rate. In sum, both of our facility measures predict an increase in an individual's illegal wage rate.

$\sim$ Table 5 about here 
The magnitudes of the days incarcerated coefficients are difficult to concretely interpret in isolation as they are quite small and the unit (days) has a large range. However, they can be transformed into marginal effects to better understand the nature of the days incarcerated effect. For example, the results from the fully specified model in column 5 indicate that for an individual at the first quintile of cumulative days incarcerated, holding all else constant, an additional 30 days of incarceration would yield a $2.9 \%$ increase in the daily illegal wage rate. ${ }^{19}$ For an individual earning the average daily illegal wage rate in the sample, this would translate into an additional $\$ 172$ per month. For an individual at the top quintile of cumulative days incarcerated, however, an additional 30 days of incarceration would only yield a $0.9 \%$ increase in daily wage rate, as this effect is marginally declining. We note, however, that over the entire support of the cumulative days range in the data, this marginal effect would be strictly positive.

Finally, we note that the magnitude of the facility peer exposure coefficient is positive and statistically significant in each of our model specifications. The magnitude of this coefficient is dramatically reduced in the fixed effects specification, which is highly indicative of selection. Moreover, in the fully specified model which includes both days incarcerated and peer exposure, the magnitude of the peer exposure effect is reduced by approximately $40 \%$, which is expected since these two variables are strongly positively correlated. ${ }^{20}$ Yet, even in the fully specified model, each increase in peer exposure category is worth about an $11 \%$ increase in illegal returns. Our findings indicate that there is both a peer exposure effect, which is indicative of a criminal capital 'crime school' effect, and an additional facility effect. This suggests there are perhaps

\footnotetext{
${ }^{19}$ We evaluated this marginal effect in our log-linear model using the model coefficients to generate the following formula: [.001 - 2(5.29E-7)(40)] $* 30$, where 40 is the first quintile of cumulative days incarcerated and 30 is the size of the dosage.

${ }^{20}$ Ideally, we would have specified the model as a personXdays dosage and fit the model nonparametrically. However, our measure of facility peer exposure was categorical and prevented such a specification.
} 
additional mechanisms—-signaling, for instance — at work beyond a pure crime school explanation.

\section{DISCUSSION}

Understanding the unintended consequences of institutionalization has important policy and theoretical implications. In the most immediate sense, institutionalization produces heavy burdens on the correctional system (as well as the communities from which offenders come from and subsequently return to) and has often showed criminogenic effects. In the longer term, incarcerating offenders can have consequences that are possibly even more deleterious:

incarceration can foster opportunities to learn criminal rationalizations, skills, and techniques for offending. Given the accumulating evidence within the rational choice and desistance literature that shows that offenders are highly sensitive to rewards (Piquero et al., 2011), individuals who have greater returns to crime are less likely to enter the desistance process. Although underexplored, increasing the rewards from crime has important consequences as it can alter criminal trajectories and can be extremely costly both financially and in terms of additional crimes and future incarceration.

In light of the short term and long term consequences of incarceration, the current study investigated a relatively neglected line of inquiry. Using a unique sample of serious adolescent offenders that have been followed over seven years, we considered whether institutions are schools of crime in the sense that they facilitate greater returns to crime. To address some of the shortcomings of previous studies that have looked at institutions as a school for 'crime school' effect, we used two different but complementary predictors of institutional experiences and modeled our outcome as an illegal wage rate, which allowed us to isolate the criminal capital effect. Several important findings emerged. 
First, both our facility measures, total number of days incarcerated and exposure to deviant peers, predict a positive increase in an individual's daily illegal wage rate, even after eliminating fixed unobserved heterogeneity and controlling for important time-varying confounders such as criminal experience and level of criminal embeddedness. For total number of days institutionalized, there were positive though marginally declining returns to length of stay. This suggests that there is perhaps a low learning curve to acquiring such criminal capital, and short term stays are just as useful to an offender as longer term stays. This finding adds further complexity to the task of examining length of institutionalization and future recidivism. For example, the relationship between institutional length and recidivism appears to be nonlinear. Some scholars have found that shorter terms of institutionalization can lead to higher rates of recidivism (Abrams, 2011; Bushway and Owens, 2010). Institutionalization carries with it tangible costs such as monitoring, housing and feeding offenders, and intangible costs such as loss of freedom and lost pro-social opportunities. To fully consider the costs and benefits of incarceration, offenders' accumulation of criminal capital should be one of the key considerations. Our results seem to suggest that, based on capital accumulation and access to new social opportunities, for some offenders being incarcerated during a portion of their criminal career might actually be rewarding.

In addition to the number of days institutionalized, there is a positive relationship between the number of friends within facilities who engaged in income-generating crime and reported subsequent illegal wages. This finding supports the notion that institutions are schools of crime, suggesting that individuals learn definitions, techniques, skills and acquire information from peers within the facility. This is in line with the portrayal of the accumulation of a conventional form of criminal capital — human capital. More specifically, some sociologists 
describe education (the formation of skills and knowledge) as a process that requires

socialization (Coleman, 1988; Granovetter, 1985). For example, Coleman (1988) emphasized the importance of family members and community members in developing human capital in children. Similarly, criminologists have illustrated a process whereby offenders gain knowledge and skills from more experienced offenders (e.g., Cloward and Ohlin, 1960; Sutherland, 1931). In this view, institutions serve as schools of crime because the primary source in formation of criminal capital is from direct exposure to peers within the correctional institution. Our results harmonize with this view that education is obtained through a process of socialization. More specifically, friends within a facility are a salient source of criminal capital, which can help in achieving greater monetary rewards from crime.

Given that our measure reflects the number of friends who had experience with incomegenerating crimes during institutionalization, we are unable to determine the precise mechanisms of criminal capital formation. For instance, direct mentoring or tutelage from friends within the facility or simply the transference of information both add to criminal capital but can have very different outcomes upon release (McCarthy and Hagan, 1995; Morselli et al., 2006).

Although an individual's friends during institutionalization have a positive and significant effect on the illegal wage rate, it does not fully mediate the positive effects of the number of days institutionalized. Both predictors exerted independent effects on an offender's illegal wage rate, suggesting that there are mechanisms beyond the accumulation of criminal capital that increases a subject's illegal wage rate. One theoretical perspective that offers some insight into why being incarcerated may increase illegal wage rates is the signaling perspective. Even though both human capital theory and the signaling perspective would predict that incarceration can increase illegal wage rate, they highlight different processes. A signaling 
theoretical explanation could indicate to other illegal market participants that, by 'investing' time in institutions, the individual has made an escalation of commitment to a deviant lifestyle and is a capable and committed illegal market operator in the future.

It is a worthy endeavor to examine the explanatory value of signaling theory in the criminal context. For example, criminologists can use signaling theory to show how actions might signal particular unobservable attributes and provide benefits to both signaler and observers. There have been recent strides to apply signaling theory to prisoner re-entry (e.g., Bushway and Apel, 2012); however, the signaling perspective is also valuable for understanding the illegal market. One basic tenet of the perspective is that individuals look to signals under circumstances of uncertainty (Arrow, 1978). For example, employers look for indices of productivity when hiring individuals. There are few endeavors that carry the inherent risks and uncertainty as criminal behavior. For example, criminal co-operation is a highly risky enterprise as co-offenders can be inept or untrustworthy (McCarthy, Hagan and Cohen, 1998). Criminal offending groups are often ephemeral and potential co-offenders are often faced with incomplete information regarding the trustworthiness and competence of their co-offenders. Thus, failures and mistakes can be costly due to the loss of opportunity for fruitful cooperation (Bacharach and Gambetta, 2001). Moreover, the costs of signaling should be negatively associated with productivity. Costs generally incorporate a number of things including psychological costs, monetary costs, or time costs (Spence, 1792). Thus, offenders who have been incarcerated can choose to signal to the illegal job market that he/she has experience and is committed to the criminal lifestyle. ${ }^{21}$

\footnotetext{
${ }^{21}$ An alternative behavioral explanation for this finding is the sunk cost fallacy. In other words, some individuals may view their time in incarceration as a sunk cost, and the need to justify it by continuing to produce returns to this 'investment' may lead some individuals to irrationally conclude that continuing participation in illegal activities is merited. As the present study includes no behavioral intentions to assess this possibility, it remains a speculation in need of empirical research.
} 
Another potential reason why facility peers did not fully mediate the effects of the total number of days incarcerated is that our measure of facility peer exposure was based on questions that asked subjects about the criminal behavior of their friends within the correctional facility. It is likely that subjects were also exposed to and influenced by other individuals during their incarceration whom they did not consider friends. In line with Granovetter's (1973) strength of weak ties argument, not all contacts made in prison are necessarily friendship ties. Offenders are exposed to individuals in correctional facilities whom they would not likely encounter in their day to day life. These acquaintances can become valuable sources of social capital by providing new and novel information about criminal opportunities. They can also be important bridges between different groups of individuals who would otherwise be unconnected.

We also found non-trivial bias due to selection, even within a sample of relatively serious offenders which must be accounted for in studying the effects of incarceration. When comparing our OLS model to the fixed effects model, several important differences emerged. Most notably our facility measures, total number of days incarcerated and facility peer exposure, were twice as large in the OLS model compared to the fixed effect model, suggesting that if selection was not accounted for, the estimates would be bias upward. More recently, selection bias has been recognized as a pervasive problem in the criminological literature in general and in identifying incarceration effects in particular. Although the issue of selection is not always problematic, careful consideration of selection bias should be of primary importance.

Third, it is important to recognize that proximate factors were very important to greater illegal wage rates. Guided by human capital theory and previous work on criminal capital, we included five time varying covariates in our models. Consistent with prior work, we found that there was a nonlinear marginal return to criminal experience (Uggen and Thompson, 2003). 
Criminal embeddedness also exerted a positive and significant effect on the illegal wage rate, suggesting that increases in an offender's friends within the community are important. Our measure of income offending variety also surfaced as an important positive predictor of within individual change in the illegal wage rate. The greater number of income-generating crimes a person engages in, the higher his/her illegal wage rate. On the surface, this is at odds with prior studies that have found that individuals who specialize have greater illegal wages (e.g., McCarthy and Hagan, 2001). One potential explanation is that our measure was restricted to types of crimes within the income-generating crimes category rather than the number of crime types across all categories of crime. ${ }^{22}$ These findings suggest that although experiences within correctional facilities have an important impact on an offender's illegal wage rate, experiences and contacts accumulated outside of correctional facilities cannot be overlooked.

For juveniles, placement in institutions can have important negative consequences. Prior to this study, findings from the Pathways Study have found evidence both that institutional placement has a null or perhaps even a criminogenic effect on recidivism and that longer lengths of stay yield no marginal deterrent effect (Loughran et al., 2009). Our findings extend and complement these findings showing that institutionalization might also serve to increase opportunities in the illegal market. In addition to increasing the likelihood of recidivism upon release, adolescents are denied the opportunities to build conventional human capital and social capital, which has consequences for later opportunities (Mulvey and Schubert, 2012a). Instead, correctional facilities provide opportunities for adolescents to develop criminal capital and criminal social capital. Except for assessing the efficacy of treatment programs within prisons, offender experiences within correctional facilities are rarely studied and prison experiences are

\footnotetext{
${ }^{22}$ McCarthy and Hagan (2001) used engaging in drug crimes only as their measure of specialization. Drug crimes are unique and are qualitatively different from other types of crime (Thompson and Uggen, 2012)
} 
often referred to as the "black box" (Clear, 1996). However, experiences during incarceration can have profound effects on future outcomes, especially during adolescence. As Clear (1996:1) notes, incarceration has "unforeseen effects [that] are subtle and, in some ways, modest, but over time they combine to counteract the positive effects of prison. A broader, more complete understanding of the effects of incarceration would enable us to understand the limits of using prison as a crime-prevention strategy". In the current study, we revealed an important and unintended consequence of incarceration: the formation of criminal capital. This not only undermines prison as a crime-prevention strategy but could also promote longer and more successful criminal careers. 


\section{REFERENCES}

Abrams, David S. 2011. Building criminal capital vs specific deterrence: The effect of incarceration length on recidivism. Working Paper.

Agnew, Robert. 1992. Foundation for a general strain theory of crime and delinquency. Criminology 30(1): 47-87.

Anderson, Elijah. 1999. Code of the Street: Decency, Violence and the Moral Life of the Inner City. New York: W. W. Norton.

Angrist, Joshua and Alan B. Krueger. 1991. Does compulsory school attendance affect schooling and earnings. Quarterly Journal of Economics 106: 979-1014.

Angrist, Joshua D. and Jorn-Steffen Pischke. 2009. Mostly Harmless Econometrics: An Empiricist's Companion. Princeton, NJ: Princeton University Press.

Arrow, Kenneth. 1973. Higher education as a filter. Journal of Public Economics 2(3): 193-216.

Bales, William D. and Alex R. Piquero. 2011. Assessing the Impact of Imprisonment on Recidivism. Journal of Experimental Criminology 8:71-101.

Bayer, Patrick, Randi Hjalmarsson and David Pozen. 2009. Building criminal capital behind bars: Peer effects in juvenile corrections. The Quarterly Journal of Economics 124(1): 105-147.

Beck, Allen and Paige M. Harrison. 2008. Sexual Victimization in State and Federal Prisons Reported by Inmates, 2007. Washington, DC: U.S. Department of Justice, Office of Justice Programs, Bureau of Justice Statistics.

Becker, Gary, S. 1962. Investment in human capital. A theoretical analysis. The Journal of Political Economy 70(5): 9-49.

Becker, Howard S. 1963. Outsiders. New York: The Free Press.

Berecochea, John. and David Jaman. 1981. Time Served in Prison and Parole Outcome: An Experimental Study. Report 2. Sacramento: California Department of Corrections.

Berube, Danton, and Donald P. Green. 2007. The effects of sentencing on recidivism: Results from a natural experiment. Unpublished manuscript. New Haven, CT: Yale University.

Bishop, Donna and Charles Frazier. 2000.Consequences of transfer. In The Changing Borders of Juvenile Justice: Transfer of Adolescents to the Criminal Court, eds Jeffery. Fagan and Frank Zimring. Chicago: University of Chicago Press.

Blomberg, Thomas, William D. Bales, Karen Mann, Alex R. Piquero, and Richard Berk. 2011. Incarceration, education and transition from delinquency. Journal of Criminal Justice 39:355365.

Bouchard, Martin and Holly Nguyen. 2010. Is it who you know or how many that counts? Justice Quarterly 27(1): 130-158. 
Bound, John, David A. Jaeger, and Regina M. Baker. 1990. Problems with instrumental variables estimation when the correlation between the instruments and the endogenous explanatory variable is weak. Journal of the American Statistical Association 90(430): 443-450.

Burt, Ronald S. 1992. The Social Structure of Competition. Cambridge, MA: Harvard University Press.

Bushway, Shawn D. and Apel, Robert. 2012. A signaling perspective on employment-based reentry programming. Criminology and Public Policy 11(1): 21-50.

Card, David. 1995. Using geographic variation in college proximity to estimate the return to schooling. In Aspects of Labour Market Behaviour: Essays in honour of John Vanderkamp, eds. Louis N. Christofides, E. Kenneth Grant and Robert Swidinsky University of Toronto Press, Toronto, Canada.

Card, David. 1999. The causal effect of education on earnings. In The Handbook of Labor Economics, vol 3A., eds Orley Ashenfelter and David Card. Amsterdam and New York: North Holland.

Carneiro, Pedro, James J. Heckman and Edward J. Vytlacil 2011. Estimating marginal returns to education. American Economic Review 101(6): 2754-2781.

Caspi, Avshalom, Terrie E. Moffitt, Arland Thornton, Deborah Freedman, J.W. Amwell, Hona Lee Harrington, J. Smeijers., and Phil A. Silva. 1996. The life history calendar: A research and clinical assessment method for collecting retrospective event-history data. International Journal of Methods in Psychiatric Research 6(2): 101-114.

Chen, Keith M., and Jesse M. Shapiro. 2007. Do harsher prison conditions reduce recidivism? A discontinuity-based approach. American Law and Economics Review 9(1): 1-29.

Clear, Todd. 1996. Backfire: When Incarceration Increases Crime. Journal of the Oklahoma Criminal Justice Research Consortium 3(2): 1-10.

Clear, Todd R., Dina R. Rose, and Judith A. Ryder. 2001. Incarceration and the community: The problem of removing and returning offenders. Crime and Delinquency 47(3): 335-351.

Cloward, Richard A., and Lloyd E. Ohlin. 1960. Delinquency and Opportunity. Glencoe, IL: Free Press.

Cohen, Mark A. and Alex R. Piquero. 2009. New evidence on the monetary value of saving a high risk youth. Journal of Quantitative Criminology 25:25-49.

Coleman, James. S. 1988. Social capital in the creation of human capital. The American Journal of Sociology 94: S95-S120.

Dishion, Thomas J., and Kenneth A. Dodge. 2005. Peer contagion in interventions for children and adolescents: Moving towards an understanding of the ecology and dynamics of change. Journal of Abnormal Child Psychology 33(3),395-400. 
Dishion, Thomas J., Joan McCord, and Francois Poulin. 1999. When interventions harm: Peer groups and problem behavior. American Psychologist 54(9), 755-764.

Dmitrieva, Julia, Kathryn C. Monahan, Elizabeth Cauffman and Laurence Steinberg. 2012. Arrested development: The effects of incarceration on the development of psychosocial maturity. Development and Psychopathology 24(3): 1073-1090.

Drago, Francesco, Roberto Galbiati, and Pietro Vertova. 2009. The deterrent effects of prison: evidence from a natural experiment. Journal of Political Economy 117(2): 257-280.

Dustmann, Christian and Maria Rochina-Barrachina. 2007. Selection correction in panel data models: An application to the estimation of females' wage equations. Econometrics Journal, 10: 263-293.

Fagan, Jeffrey, and Richard B. Freeman. 1999. Crime and work. In Crime and Justice: A Review of Research vol. 25, ed. by Michael Tonry. Chicago: University of Chicago Press.

Fagan, Jeffrey; Valerie West, and Jan Holland. Neighborhood, crime, and incarceration in New York City. Fordham Urban Law Journal 30: 1551-1602.

Feldman Ronald A, Timothy E. Caplinger. 1977. Social work experience and client behavioral change: Multivariate analysis of process and outcome. Journal of Social Service Research 1(1):5-33.

Feldman, Ronald A. Timothy E Caplinger, and John S. Wodarski. 1983. St Louis Conundrum The Effective Treatment of Antisocial Youths. Englewood Cliffs, NJ: Prentice Hall.

Gaes, Gerald G. and Scott D. Camp. 2009. Unintended consequences: experimental evidence for the criminogenic effect of prison security level placement on post-release recidivism. Journal of Experimental Criminology 5(2): 139-162.

Gambetta, Diego. 2009. Codes of the Underworld: How Criminals Communicate. Princeton NJ: Princeton University Press.

Gatti, Uberto, Richard E. Tremblay, and Frank Vitaro. 2009. Iatrogenic effect of juvenile justice. The Journal of Child Psychology and Psychiatry 50:991-998.

Gottfredson, Michael R., and Travis Hirschi. 1990. A General Theory of Crime. Stanford, CA: Stanford University Press.

Granovetter, Mark. 1973. The strength of weak ties. American Journal of Sociology 78(6): 13601380 .

Granovetter, Mark. 1985. Economic action and social structure: The problem of embeddedness. American Journal of Sociology 91(3): 481-510.

Green, Donald P. and Daniel Winik. 2010. Using random judge assignments to estimate the effects of incarceration and probation on recidivism among drug offenders. Criminology 48(2): 357-387 
Gronau, Reuben. 1974. Wage comparisons-a selectivity bias. Journal of Political Economy 82(6): 1119-1143.

Hagan, John. 1993. The social embeddedness of crime and unemployment. Criminology 31(4): 465-491.

Haviland, Amelia M., and Daniel S. Nagin. 2005. Causal inferences with group based trajectory models. Psychometrika 70(3): 557-578.

Harding, David J. 2009. Violence, older peers, and the socialization of adolescent boys in disadvantaged neighborhoods. American Sociological Review, 74: 445-464.

Haynie, Dana L., and D. Wayne Osgood. (2005). "Reconsidering Peers and Delinquency: How do Peers Matter?” Social Forces, 84, 2, 1109-1130.

Heckman, James. 1974. Shadow prices, market wages, and labor supply. Econometrica 42(4): 679-694.

Hjalmarsson, Randi. 2009. Juvenile jails: A path to the straight and narrow or to hardened criminality? Journal of Law and Economics 52(4), 779-809

Horney, Julie, D. Wayne Osgood and Ineke H. Marshall. 1995. Criminal careers in the shortterm: intra-individual variability in crime and its relation to local life circumstances. American Sociological Review 60(5): 655-673.

Hutcherson, Donald T. 2012. Crime pays: The connection between time in prison and future criminal earnings. The Prison Journal, 92: 351-335.

Jacobs, Bruce A. 1996. Crack dealers' apprehension avoidance techniques: A case of restrictive deterrence. Justice Quarterly 13(3): 359-381.

Kazemian, Lila and Marc LeBlanc. 2007. Differential cost avoidance and successful criminal careers: Random or rational? Crime and Delinquency 53(1): 38-63.

Laub, John H. and Robert J. Sampson. 2003. Shared Beginnings, Divergent Lives: Delinquent Boys to Age 70. Cambridge, MA: Harvard University Press.

Lemert, Edwin. 1973. Human Deviance, Social Problems and Social Control. Englewood Cliffs, New Jersey: Prentice-Hall Inc.

Leve, Leslie, D. and Patricia Chamberlain. 2005. Association with delinquent peers: Intervention effects for youth in the juvenile justice system. Journal of Abnormal Child Psychology 33(3): 339-347.

Levitt, Steven. D, and Sudhir A. Venkatesh. 2000. An economic analysis of a drug-selling gang's finances. The Quarterly Journal of Economics 115(3): 755-789.

Lin, Nan. 2001. Social Capital: A Theory of Social Structure and Action. Cambridge University Press, Cambridge. 
Listwan, Shelley J., Christopher J. Sullivan, Robert Agnew, Francis T. Cullen and Mark Colvin. 2013. The pains of imprisonment revisited: The impact of strain on inmate recidivism. Justice Quarterly 30(1): 144-168.

Lofland, John 1969. Deviance and Identity. Englewood Cliffs, NJ: Prentice-Hall.

Loughran Thomas A. Edward P. Mulvey, Carol A. Schubert, Jeffery Fagan, Alex R. Piquero, and Sandra H. Losoya. 2009. Estimating a dose-response relationship between length of stay and future recidivism in serious juvenile offenders. Criminology 47:699 - 740.

Thomas A. Loughran, Edward P. Mulvey, Carol A. Schubert, Laurie A. Chassin, Laurence Steinberg, Alex R. Piquero, Jeffrey Fagan, Sonia Cota-Robles, Elizabeth Cauffman, and Sandy Losoya. 2010. Differential Effects of Adult Court Transfer on Juvenile Offender Recidivism. Law and Human Behavior, 34:476-488.

Manski, Charles F. and Daniel S. Nagin. 2005. Bounding disagreements about treatment effects: A case study of sentencing and recidivism. Sociological Methodology 28(1): 99-137.

Manza, Jeff and Chris Uggen. 2006. Locked Out: Felon Disenfranchisement and American Democracy. New York: Oxford University Press.

Mayhew, Henry. 2011. The Criminal Prisons of London: and Scenes of Prison Life. Cambridge, UK: Cambridge University Press.

Mayhew, Henry. 2012. London Labour and the London Poor. New York: Oxford University Press.

McCarthy, Bill, and John Hagan. 1995. Getting into street crime: The structure and process of criminal embeddedness. Social Science Research 24: 63-95.

McCarthy, Bill and John Hagan. 2001. When crime pays: Capital, competence, and criminal success. Social Forces 79(3): 1035-1059.

McCord, Joan. 1978. A thirty-year follow-up of treatment effects. American Psychologist 33: 285-289.

McCord, Joan. 1981. Consideration of some effects of a counseling program. In New Directions in the Rehabilitation of Criminal Offenders, eds. Susan E. Martin, Lee B. Sechrest, and Robin Redner. Washington, DC: The National Academy of Sciences.

Miller, Aiden D. and Lloyd E. Ohlin. 1985. Delinquency and Community: Creating Opportunities and Controls. Rockville, MD. National Institute of Justice.

Mincer, Jacob. 1974. Schooling, Experience and Earnings. New York: Columbia University Press.

Moore, Joan. 1996. Bearing the burden: How incarceration weakens inner-city communities. The Unintended Consequences of Incarceration. New York City: The Vera Institute. 
Morris, Nancy A. and Lee Ann Slocum. 2010. The validity of self-reported prevalence, frequency, and timing of arrest: an evaluation of data collected using a life event calendar. Journal of Research in Crime and Delinquency 47: 210-240.

Morselli, Carlo, and Tremblay, Pierre. 2004. Criminal achievement, offender networks and the benefits of low self-control. Criminology 42(3): 773-804.

Morselli, Carlo, Pierre Tremblay and Bill McCarthy. 2006. Mentors and criminal achievement. Criminology 44(1): 17-43.

Mulvey, Edward., and Carol Schubert. 2012a. Youth in prison and beyond. In The Oxford Handbook on Juvenile Crime and Juvenile Justice, eds. Barry Feld and Donna Bishop. New York, NY: Oxford University Press.

Mulvey, Edward and Carol Schulbert. 2012b. Transfer of Juveniles to Adult Court:Effects of a Broad Policy in One Court. Juvenile Justice Bulletin, Washington, DC: Office of Juvenile Justice and Delinquency Prevention.

Mulvey, Edward. P., Laurence Steinberg, Jeffery Fagan, Elizabeth Cauffman, Alex Piquero, Laurie Chassin, George Knight, Robert Brame, Carol Schubert, Thomas Hecker, and Sandra Losoya. 2004. Theory and research on desistance from antisocial activity among serious juvenile offenders. Youth Violence and Juvenile Justice 2: 213-36.

Nagin, Daniel S., Francis T. Cullen, and Cheryl Lero Jonson. 2007. Imprisonment and reoffending. In Crime and Justice: A Review of Research, vol. 38, ed. by Michael Tonry. Chicago: University of Chicago Press.

Nagin, Daniel S. and Ray Paternoster. 1991. Enduring individual differences and rational choice theories of crime. Law and Society Review 27: 467-496.

Nieuwbeerta, Paul, Daniel S. Nagin, and Arjan A. J. Blokland. 2009. Assessing the impact of first-time imprisonment on offenders' subsequent criminal career development: A matched samples comparison. Journal of Quantitative Criminology 25(3): 227-257.

Office of Juvenile Justice and Delinquency Prevention. 2012. Statistical Briefing Book. Washington, DC: US Department of Justice.

Ouss, Aurelie. 2011. Prison as a school of crime: Evidence from cell-level interactions. Working paper Available at SSRN: http://ssrn.com/abstract=1989803 or http://dx.doi.org/10.2139/ssrn.1989803.

Padilla, Felix M. 1992. The Gang as an American Enterprise. New Brunswick: Rutgers University Press.

Pager, Devah. 2007. Marked: Race, Crime, and Finding Work in an Era of Mass Incarceration. Chicago: University of Chicago Press.

Petersilia, Joan. 2003. When Prisoners Come Home: Parole and Prisoner Reentry. New York, NY: Oxford University Press. 
Pezzin, Liliana E. 1995. Earning prospects, matching effects, and the decision to terminate a criminal career. Journal of Quantitative Criminology 11:29-50.

Piliavin, Irving, Rosemary Gartner, Craig Thornton and Ross L. Matsueda. 1986. Crime, deterrence and rational choice. American Sociological Review 51: 101-119.

Piquero, Alex R., Raymond Paternoster, Greg Pogarsky, and Thomas Loughran. 2011. Elaborating the individual difference component in deterrence theory. Annual Review of Law and Social Science 7:335-360.

Poulin, Francois, Thomas J. Dishion and Bert Burraston. 2001. 3-Year iatrogenic effects associated with aggregating high-risk adolescents in cognitive-behavioral preventive interventions. Applied Developmental Science 5(4): 214-224.

Richardson, Ruth. 2012. Dickens and the Workhouse: Oliver Twist and the London Poor. New York: Oxford University Press.

Roberts, Jennifer and Julie Horney. 2010. The life event calendar method in criminological research. In The Handbook of Quantitative Criminology. Eds. Alex R. Piquero and David Weisburd. New York: Sage.

Sampson, Robert J. and John H. Laub. 1993. Crime in the Making: Pathways and Turning Points Through Life. Cambridge, MA: Harvard University Press.

Schubert, Carol. A., Edward P. Mulvey, Laurence Steinberg, Elizabeth Cauffman, Sandra H. Losoya, Thomas Hecker, Laurie Chassin and George P. Knight. 2004. Operational lessons from the Pathways to Desistance Project. Youth Violence and Juvenile Justice 2: 237-255.

Shaw, Clifford R. 1966. The Jack Roller: A Delinquent Boy's Own Story. Chicago: University of Chicago Press.

Shaw, Clifford R. and Henry D. McKay. 1931. The Natural History of a Delinquency Career. Chicago IL: University of Chicago Press.

Shaw, Clifford R. and Henry D. McKay (1942). Juvenile Delinquency in Urban Areas. Chicago: University of Chicago Press.

Shover, Neal, and Carol Y. Thompson. 1992. Age, differential expectations, and crime desistance. Criminology 30: 89-104.

Snodgrass, Matthew G., Arjan A. J Blokland, Amelia Haviland, Paul Nieuwbeerta, Daniel S. Nagin. 2011. Does the time cause the crime? An examination of the relationship between time served and reoffending in the Netherlands. Criminology 49(4), 1149-1194.

Snyder, Howard N. 2004. An empirical portrait of the youth reentry population. Youth Violence and Juvenile Justice 2(1): 39-55.

Spence, Michael. 1973. Job market signaling. The Quarterly Journal of Economics 87(3): 355374. 
Spohn, Cassia and David Holleran. 2006. The effect of imprisonment on recidivism rates of felony offenders: A focus on drug offenders. Criminology 40(2), 329-358.

Steffensmeier, Darrell, J and Jeffery T. Ulmer. 2005. Confessions of a Dying Thief: Understanding Criminal Careers and Illegal Enterprise. New Brunswick, NJ: Transactions Publishers.

Sullivan, Mercer L. 1989. Getting Paid: Youth Crime and Work in the Inner City. Ithaca, NY: Cornell Univ. Press.

Sutherland, Edwin H. 1937. The Professional Thief. Chicago, Il: University of Chicago Press.

Sutherland, Edwin H. 1947. The Principles of Criminology. Philadelphia, Penn: J. B. Lippincott.

Thompson, Melissa, and Christopher Uggen. 2012. Dealers, thieves, and the common determinants of drug and nondrug illegal earnings, Criminology 50(4): 1057-1087.

Thornberry, Terence, Alan J. Lizotte, Marvin Krohn, Margaret Farnworth and Sung J. Jang. 1994. Delinquent peers, beliefs, and delinquent behavior: A longitudinal test of interactional theory. Criminology 32(2), 47-83.

Tillman, Robert and Michael Indergaard. 1999. Field of schemes: Health insurance fraud in the small business sector. Social Problems 46(4): 572-590.

Tonry, Michael H. 1999. The fragmentation of sentencing and corrections in America. Sentencing and Corrections, Issues for the 21st Century, no. 1. Washington, D.C.: U.S. Department of Justice, National Institute of Justice.

Topalli, Volkan. 2005. Criminal expertise and offender decision-making. British Journal of Criminology 45: 269-295.

Turner, Emily. 2009. Using Random Case Assignment and Heterogeneity in Attorney Ability to Examine the Relationship Between Sentence Length and Recidivism. Unpublished dissertation, University of Pennsylvania.

Uggen, Chris and Melissa Thompson. 2003. The socioeconomic determinants of ill-gotten gains: within-person changes in drug use and illegal earnings. American Journal of Sociology 109(1): 146-185.

Vella, Francis and Marno Verbeek. 1999. “Two-step estimation of panel data models with censored endogenous variables and selection bias". Journal of Econometrics, 90(2): 239-263.

Western, Bruce. 2006. Punishment and Inequality in America. New York: Russell Sage.

Wooldridge, Jeffrey, M. 1995. "Selection corrections for panel data models under conditional mean independence assumptions". Journal of Econometrics, 68: 115- 132.

Wooldridge, Jeffery M. 2002. Econometric Analysis of Cross Section and Panel Data. Mason, $\mathrm{OH}$ : MIT Press. 
Wooldridge, Jeffery M. 2009. Introductory Econometrics: A Modern Approach. Mason, OH: MIT Press.

Wright, Richard and Scott Decker. 1994. Burglars on the Job: Streetlife and Residential BreakIns. Boston: Northeastern University Press.

Zimring, Frank.E. 2005. American Juvenile Justice. New York, NY: Oxford University Press. 
Figure 1. Histogram of log daily illegal wage rate.

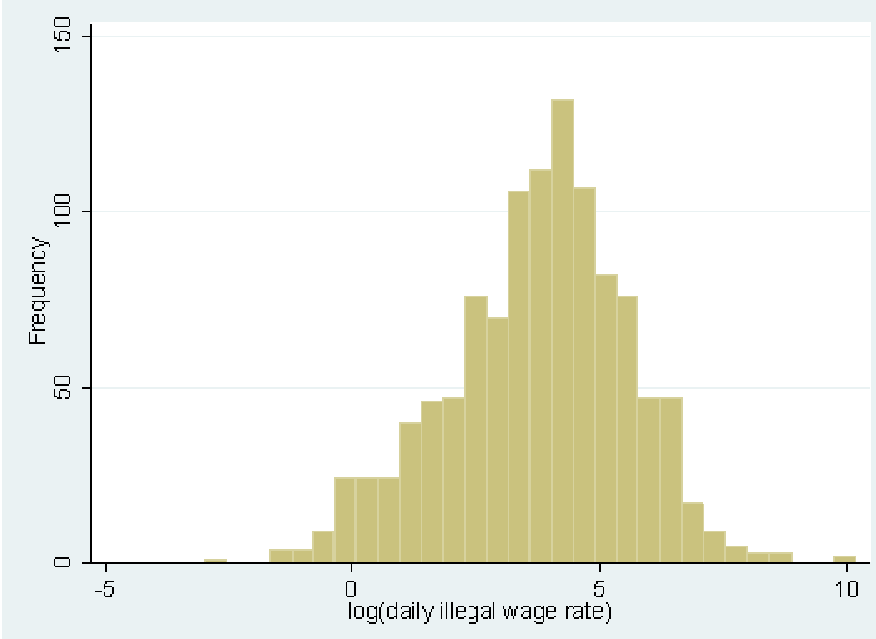


Figure 2. First difference in log illegal wage rate.

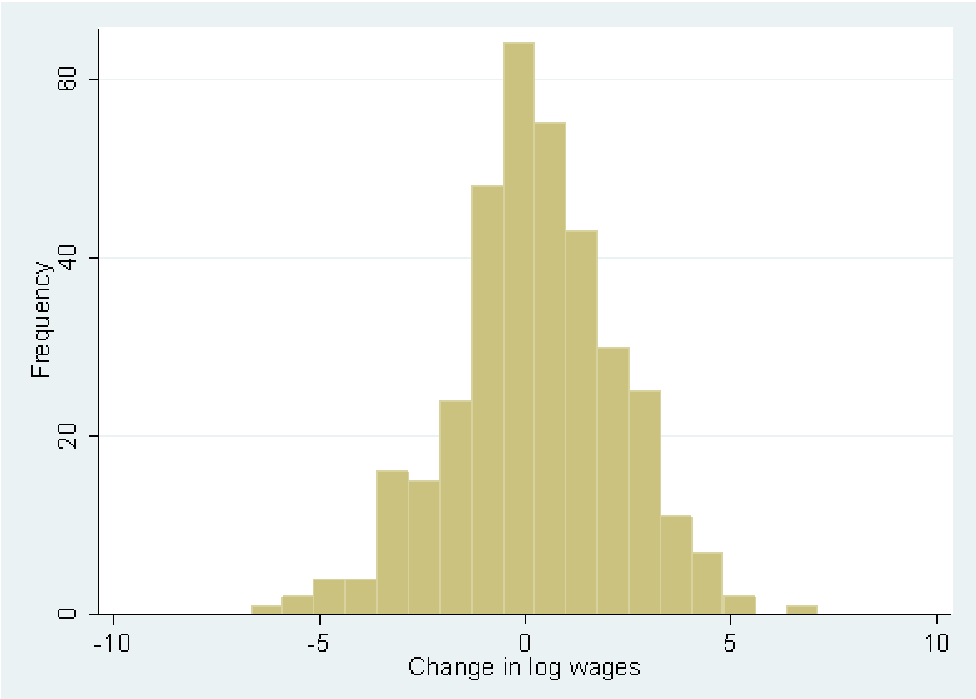


Figure 3. Log illegal wage rate by custody.

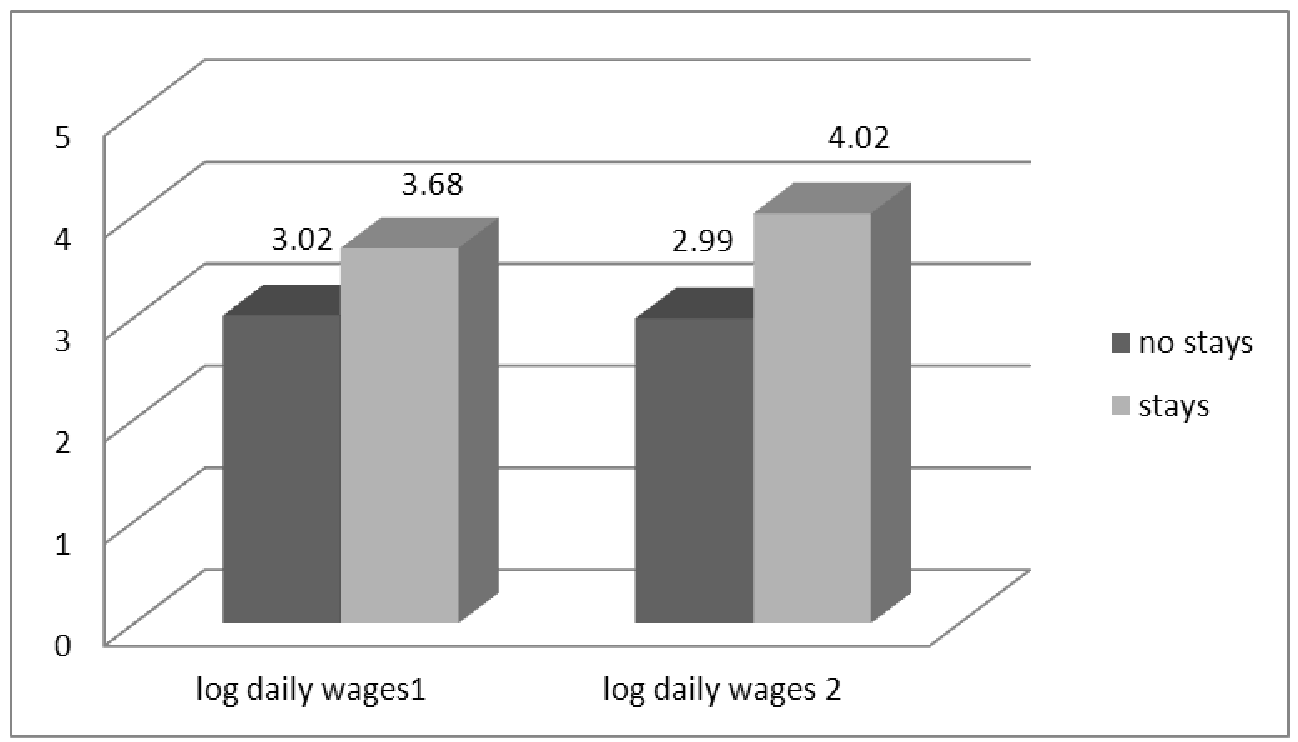


Table 1. Descriptive of sample $(n=352)$.

\begin{tabular}{lccccc}
\hline & Mean & S.d. & Median & Q1 & Q3 \\
\hline Daily wages & 205.04 & 1087.74 & 50.88 & 13.80 & 144.44 \\
Log daily wages & 3.75 & 1.83 & 3.93 & 2.63 & 4.97 \\
Days incarcerated & & & & & \\
$\quad$ waves 1 to 6 & 65.08 & 74.64 & 25 & 0 & 137.50 \\
$\quad$ waves 7 to 10 & 116.12 & 141.81 & 26 & 0 & 247.00 \\
Peer exposure (facility) & 3.39 & 1.01 & 3.5 & 3.00 & 4.00 \\
Time varying controls: & & & & & \\
Criminal experience (total frequency) & 91.83 & 296.03 & 0 & 0 & 25.00 \\
$\quad$ waves 1 to 6 & 100.31 & 260.25 & 0 & 0 & 68.00 \\
$\quad$ waves 7 to 10 & .387 & .487 & 0 & 0 & 1 \\
Adult facility & 1.85 & 0.89 & 1.50 & 1 & 2.50 \\
Criminal embeddedness & 19.71 & 2.30 & 19.40 & 18.00 & 21.36 \\
Age & 0.13 & 1.80 & 0.10 & 0 & 0.20 \\
Income variety offending & & & & \\
\hline
\end{tabular}

Waves 1 to 6 are six month follow up periods and waves 7 to 10 are one year follow up periods 
Table 2. Conditional illegal wage rate distributions.

\begin{tabular}{lcc}
\hline $\begin{array}{l}\text { Cumulative days incarcerated } \\
\text { (quintiles) }\end{array}$ & Days & Log illegal wage rate \\
\hline Q1 & 40.60 & 3.30 \\
Q2 & 199.00 & 3.85 \\
Q3 & 400.00 & 4.26 \\
Q4 & 661.00 & 4.08 \\
& & Log illegal wage rate \\
Facility peers & $\mathrm{n}$ & 2.90 \\
\hline 0 & 370 & 3.49 \\
$1.0-1.49$ & 60 & 3.94 \\
$1.5-2.49$ & 54 & 4.27 \\
$2.5-3.49$ & 200 & 4.32 \\
$3.5-4.49$ & 292 & 4.08 \\
$4.5-5.0$ & 141 &
\end{tabular}


Table 3. First difference OLS model predicting changes in log daily wages $(n=352)$.

\begin{tabular}{|c|c|c|c|c|c|}
\hline & $\begin{array}{c}\text { B(S.E.) } \\
1\end{array}$ & $\begin{array}{c}\text { B(S.E.) } \\
2\end{array}$ & $\begin{array}{c}\text { B(S.E.) } \\
3\end{array}$ & $\begin{array}{c}\text { B(S.E.) } \\
4\end{array}$ & $\begin{array}{c}\text { B(S.E.) } \\
5\end{array}$ \\
\hline$\Delta$ Days incarcerated & $\begin{array}{l}.002 * * \\
(.001)\end{array}$ & $\begin{array}{l}.002 * \\
(.001)\end{array}$ & - & - & $\begin{array}{l}.002^{*} \\
(.001)\end{array}$ \\
\hline$\Delta$ Days incarcerated sq & $\begin{array}{c}-1.46 \mathrm{e}-06^{*} \\
(6.15 \mathrm{e}-07)\end{array}$ & $\begin{array}{l}-1.03 \mathrm{e}-06 t \\
(5.96 \mathrm{e}-07)\end{array}$ & - & - & $\begin{array}{l}-9.99 \mathrm{e}-07 \dagger \\
(5.94 \mathrm{e}-07)\end{array}$ \\
\hline$\Delta$ Peer exposure (facility) & - & - & $\begin{array}{l}.167 * * \\
(.053)\end{array}$ & $\begin{array}{l}.122 \dagger \\
(.063)\end{array}$ & $\begin{array}{l}.116 t \\
(.062)\end{array}$ \\
\hline \multicolumn{6}{|l|}{ Time varying controls: } \\
\hline$\Delta$ Criminal experience & - & $\begin{array}{l}.001 * \\
(.001)\end{array}$ & - & $\begin{array}{l}.002 * \\
(.001)\end{array}$ & $\begin{array}{l}.001 * \\
(.001)\end{array}$ \\
\hline$\Delta$ Criminal experience sq & - & $\begin{array}{c}-6.69 \mathrm{e}-07^{*} \\
(3.29 \mathrm{e}-07)\end{array}$ & - & $\begin{array}{l}-7.02 \mathrm{e}-07 * \\
(3.30 \mathrm{e}-07)\end{array}$ & $\begin{array}{l}-6.43 \mathrm{e}-07 \dagger \\
(3.28 \mathrm{e}-07)\end{array}$ \\
\hline$\Delta$ Adult facility & & $\begin{array}{c}.165 \\
(.194)\end{array}$ & & $\begin{array}{c}.040 \\
(.230)\end{array}$ & $\begin{array}{l}-.072 \\
(.232)\end{array}$ \\
\hline$\Delta$ Criminal embeddedness & - & $\begin{array}{c}.030 \\
(.049)\end{array}$ & - & $\begin{array}{l}.063 \\
(.048)\end{array}$ & $\begin{array}{c}.036 \\
(.049)\end{array}$ \\
\hline$\Delta$ Age & - & $\begin{array}{l}-.086 \\
(.121)\end{array}$ & - & $\begin{array}{l}-.029 \\
(.119)\end{array}$ & $\begin{array}{l}-.073 \\
(.121)\end{array}$ \\
\hline$\Delta$ Income variety offending & - & $\begin{array}{c}2.712 * * * \\
(.544)\end{array}$ & - & $\begin{array}{c}2.524 * * * \\
(.538)\end{array}$ & $\begin{array}{c}2.691 * * * \\
(.542)\end{array}$ \\
\hline Constant & $\begin{array}{l}-.066 \\
(.144)\end{array}$ & $\begin{array}{l}-.246 \\
(.227)\end{array}$ & $\begin{array}{l}.236^{*} \\
(.106)\end{array}$ & $\begin{array}{l}-.177 \\
(.194)\end{array}$ & $\begin{array}{l}-.233 \\
(.203)\end{array}$ \\
\hline R-square & 0.028 & 0.135 & 0.028 & 0.128 & 0.145 \\
\hline
\end{tabular}

$\dagger \mathrm{p}<.10 * \mathrm{p}<.05 * * \mathrm{p}<.01$ 
Table 4. OLS model predicting log daily rates (adjusted S.E).

\begin{tabular}{|c|c|c|c|c|c|}
\hline & B (S.E.) & B (S.E.) & B (S.E.) & B (S.E.) & B (S.E.) \\
\hline & 1 & 2 & 3 & 4 & 5 \\
\hline Days incarcerated & $\begin{array}{c}.003 * * * \\
(.000)\end{array}$ & $\begin{array}{c}.002 * * * \\
(.000)\end{array}$ & - & - & $\begin{array}{c}.002 * * * * \\
(.000)\end{array}$ \\
\hline Days incarcerated sq & $\begin{array}{c}-1.21 \mathrm{e}-06^{* * * *} \\
(2.18 \mathrm{e}-07)\end{array}$ & $\begin{array}{c}-8.49 \mathrm{e}-07 * * * \\
(2.01 \mathrm{e}-07)\end{array}$ & - & - & $\begin{array}{c}-6.96 \mathrm{e}-07 * * * \\
(2.02 \mathrm{e}-07)\end{array}$ \\
\hline Peer exposure (facility) & - & - & $\begin{array}{c}.314^{* * * *} \\
(.035)\end{array}$ & $\begin{array}{c}.267 * * * \\
(.042)\end{array}$ & $\begin{array}{c}.163 * * * \\
(.042)\end{array}$ \\
\hline \multicolumn{6}{|l|}{ Time varying controls: } \\
\hline Criminal experience & - & $\begin{array}{c}.001 * * * \\
(.000)\end{array}$ & - & $\begin{array}{c}.001 * * * \\
(.000)\end{array}$ & $\begin{array}{c}.001 * * * \\
(.000)\end{array}$ \\
\hline Criminal experience sq & - & $\begin{array}{c}-1.36 \mathrm{e}-07 * * * \\
(2.01 \mathrm{e}-07)\end{array}$ & - & $\begin{array}{c}-1.35 \mathrm{e}-07 * * * * \\
(3.91 \mathrm{e}-08)\end{array}$ & $\begin{array}{c}-1.32 \mathrm{e}-07 * * * \\
(3.92 \mathrm{e}-08)\end{array}$ \\
\hline Adult facility & & $\begin{array}{l}.310^{* *} \\
(.110)\end{array}$ & & $\begin{array}{l}-.055 \\
(.141)\end{array}$ & $\begin{array}{l}-.064 \\
(.134)\end{array}$ \\
\hline Criminal embeddedness & - & $\begin{array}{l}.184 * * \\
(.062)\end{array}$ & - & $\begin{array}{l}.148 * \\
(.063)\end{array}$ & $\begin{array}{l}.157 * \\
(.063)\end{array}$ \\
\hline Age & - & $\begin{array}{c}-.101 * * \\
(.029)\end{array}$ & - & $\begin{array}{l}.024 \\
(.027)\end{array}$ & $\begin{array}{l}-.057 * \\
(.031)\end{array}$ \\
\hline Income variety offending & - & $\begin{array}{c}.403 \\
(.312)\end{array}$ & - & $\begin{array}{c}.127 \\
(.303)\end{array}$ & $\begin{array}{c}.302 \\
(.311)\end{array}$ \\
\hline constant & $\begin{array}{c}2.914 * * * \\
(.119)\end{array}$ & $\begin{array}{c}3.787 * * * \\
(.574)\end{array}$ & $\begin{array}{c}3.027 * * * \\
(.119)\end{array}$ & $\begin{array}{c}1.702 * * \\
(.547)\end{array}$ & $\begin{array}{c}2.946 * * * \\
(.598)\end{array}$ \\
\hline $\mathrm{R}$-square & 0.120 & 0.237 & 0.102 & 0.213 & 0.250 \\
\hline
\end{tabular}

${ }^{*} \mathrm{p}<.05 * * \mathrm{p}<.01 * * * \mathrm{p}<.001$

Note: standard errors are cluster-corrected at the individual level. 
Table 5. Fixed effects model predicting log daily wage rates.

\begin{tabular}{|c|c|c|c|c|c|}
\hline & B (S.E.) & B (S.E.) & B (S.E.) & B (S.E.) & B (S.E.) \\
\hline & 1 & 2 & 3 & 4 & 5 \\
\hline Days incarcerated & $\begin{array}{c}.002 * * * \\
(.000)\end{array}$ & $\begin{array}{c}.002 * * \\
(.000\end{array}$ & - & - & $\begin{array}{l}.001 * \\
(.001)\end{array}$ \\
\hline Days incarcerated sq & $\begin{array}{c}-9.07 \mathrm{e}-07 * * * \\
(2.50 \mathrm{e}-07)\end{array}$ & $\begin{array}{l}-6.33 \mathrm{e}-07 * \\
(2.67 \mathrm{e}-07)\end{array}$ & - & - & $\begin{array}{c}-5.46 \mathrm{e}-07 * \\
(2.67 \mathrm{e}-07)\end{array}$ \\
\hline Peer exposure (facility) & - & - & $\begin{array}{c}.190 * * * \\
(.034)\end{array}$ & $\begin{array}{c}.149 * * * \\
(.042)\end{array}$ & $\begin{array}{l}.140 * * \\
(.042)\end{array}$ \\
\hline \multicolumn{6}{|l|}{ Time varying controls: } \\
\hline Criminal experience & - & $\begin{array}{c}.001 * * * \\
(.000)\end{array}$ & - & $\begin{array}{c}.001 * * * \\
(.000)\end{array}$ & $\begin{array}{c}.001 * * \\
(.000)\end{array}$ \\
\hline Criminal experience sq & - & $\begin{array}{c}-8.42 \mathrm{e}-08 * * \\
(2.97 \mathrm{e}-08)\end{array}$ & - & $\begin{array}{c}-8.54 \mathrm{e}-08 * * \\
(2.95 \mathrm{e}-08)\end{array}$ & $\begin{array}{c}-7.75 \mathrm{e}-08 * * \\
(2.96 \mathrm{e}-08)\end{array}$ \\
\hline Adult facility & & $\begin{array}{l}.134 \\
(.123)\end{array}$ & & $\begin{array}{l}-.114 \\
(.150)\end{array}$ & $\begin{array}{c}-.152 \\
(.149)\end{array}$ \\
\hline Criminal embeddedness & - & $\begin{array}{l}.182 * * \\
(.067)\end{array}$ & - & $\begin{array}{l}.155^{*} \\
(.067)\end{array}$ & $\begin{array}{l}.159 * \\
(.067)\end{array}$ \\
\hline Age & - & $\begin{array}{l}-.021 \\
(.044)\end{array}$ & - & $\begin{array}{l}.069 * \\
(.033)\end{array}$ & $\begin{array}{l}-.001 \\
(.045)\end{array}$ \\
\hline Income variety offending & - & $\begin{array}{c}1.395 * * * \\
(.346)\end{array}$ & - & $\begin{array}{c}1.342 * * * \\
(.344)\end{array}$ & $\begin{array}{c}1.408 * * * \\
(.344)\end{array}$ \\
\hline constant & $\begin{array}{c}3.201 * * * \\
(.105)\end{array}$ & $\begin{array}{c}2.520 * * * \\
(.792)\end{array}$ & - & $\begin{array}{l}.991 \\
(.647)\end{array}$ & $\begin{array}{c}2.009^{* *} \\
(.801)\end{array}$ \\
\hline Within R-square & 0.042 & 0.108 & 0.038 & 0.113 & 0.121 \\
\hline
\end{tabular}

